\title{
Impact of obesity on vitamin $D$ and calcium status
}

\author{
Shah $\mathbf{P}^{1}$, Chauhan AP \\ ${ }^{1}$ Dr. Pankil Shah, Assistant Professor, GMERS, Medical College, Gotri- Vadodara, Gujarat, ${ }^{2}$ Dr. Asutosh P Chauhan, \\ Associate Professor, GMERS, Medical college, Gotri- Vadodara, Gujarat, India. \\ Address for correspondence: Dr. Pankil Shah, Email: drpks1983@gmail.com
}

\begin{abstract}
Introduction: Obesity is associated with metabolic syndrome. Obesity is a leading preventable cause of death worldwide, with increasing rates in adults and children. Obesity is associated with vitamin D insufficiency and hyperparathyroidism, secondary hypercalcemia. The purpose of this study is to test effect of obesity on Vitamin D and calcium level. Methods: The present study investigated effect of obesity on Vitamin D and calcium level. We studied 150 Subjects with no pre-existing disease and not taking any nutritional suppliments for vitamin D. At a baseline they were asked about their family history of obesity. Subjects are investigated for 25-hydroxyvitamin D [25(OH) D] and serum Total calcium level to study effect of obesity on vitamin D and calcium status. Results: Out of 150 subjects included in the study, 107 had obesity and 43 subjects was non-obese. The Body Mass Index less than 30 is taken as cut off point for defining obesity. The mean value of 25 -hydroxyvitamin D was $13 \mathrm{ng} / \mathrm{ml}$ in the group of obese people and the same was $28 \mathrm{ng} / \mathrm{ml}$ in the group of non-obese individuals. This change was statistically significant $(\mathrm{p}<0.05)$. The mean value of serum Total calcium level was $13 \mathrm{mg} / \mathrm{dl}$ in the group of obese people and the same was $10 \mathrm{mg} / \mathrm{dl}$ in the group of non-obese individuals. This change was statistically significant $(\mathrm{p}<0.05)$. Conclusions: It is concluded that obese individuals are increased risk of developing Vitamin D Deficiency and secondary hypercalcemia.
\end{abstract}

Key Words: Obesity, Vitamin D, Calcium.

\section{Introduction}

Obesity is a medical condition in which excess body fat has accumulated to the extent that it may have a negative effect on health, leading to reduced life expectancy and/or increased health problems.

Obesity is a leading preventable cause of death worldwide, with increasing rates in adults and children. Overnutrition, obesity and the associated increased risk of noncommunicable diseases such as ischaemic heart disease, diabetes, stroke, and hypertension have

Manuscript received: $18^{\text {th }}$ Jan 2016

Reviewed: $30^{\text {th }}$ Jan 2016

Author Corrected: 09 $9^{\text {th }}$ Feb 2016

Accepted for Publication: $\mathbf{2 0}^{\text {th }}$ Feb 2016 generally been perceived as problems of developed countries.In the USA, $55 \%$ of adults are overweight and nearly a quarter are obese [1]. Obesity levels have risen sharply in Australia, Canada and Europe the prevalence of obesity doubled to $16 \%$ and continues to increase $[2,3]$. Recent reviews have reported significant increases in the prevalence of overweight and obese individuals in developing countries [4-6]. The epidemic of overweight and obesity inflicts significant disadvantages on both the individual and society. i.e. increased risk of disease and death, health care costs and reduced social status, educational attainment, and 
employment opportunities [7,8]. Obesity and overweight have become a global epidemic, and it is still increasing in both industrialized and developing countries [9]. Obesity and overweight are an increasingly prevalent nutritional disorder among children and adolescents in the world [10].

The proportion of children in the general population who are overweight and obese has doubled over the past two decades in developed and developing countries including India $[11,12]$.

Due to the difficulty of curing obesity and over weight in adults and the many long-term adverse effects of childhood obesity, the prevention of child obesity has been recognized as a public health priority [13].

Increasing evidence shows that childhood obesity and overweight have a profound influence on morbidity and mortality in adult life [13-15].

Recent studies in India and other countries revealed that obesity is becoming a growing health problem among children and adolescents, especially in urban populations.

The prevalence of common obesity has become a public health concern and various approaches to the understanding of obesity have failed to achieve any long term effect on prevention or treatment.

Different definitions have been used in studies to define childhood obesity and overweight $[16,17]$.

people are considered obese when their body mass index (BMI), a measurement obtained by dividing a person's weight by the square of the person's height, exceeds $30 \mathrm{~kg} / \mathrm{m}^{2}$ (High BMI), with the range 25 $30 \mathrm{~kg} / \mathrm{m}^{2}$ defined as overweight.
Vitamin D is a fat soluble vitamin and its synthesis in the body is dependent on multiple factors like latitude, atmospheric pollution, clothing, skin pigmentation and duration and time of exposure to sunlight.

Assessment of vitamin D status of an individual is best reflected by measurement of circulating vitamin D metabolites. Only two metabolites, namely, 25hydroxyvitamin $\mathrm{D} \quad[25(\mathrm{OH}) \quad \mathrm{D}]$ and 1 , 25dihydroxyvitamin $\mathrm{D}[1,25(\mathrm{OH}) 2 \mathrm{D}]$, have received the greatest attention in biochemical estimation of vitamin D serum $25(\mathrm{OH}) \mathrm{D}$ provides the single best assessment of vitamin D status $25(\mathrm{OH}) \mathrm{D}$ as it has a half-life of about 3 weeks, making it the most suitable indicator of vitamin D status [18].

Radioimmunoassay has been the most common method used for measuring 25(OH)D levels. [19] A classification given by Lips to define vitamin D status is as follows: mild hypovitaminosis D: 10-20 ng/ml, moderate hypovitaminosis D: $5-10 \mathrm{ng} / \mathrm{ml}$, and severe hypovitaminosis D: less than $5 \mathrm{ng} / \mathrm{ml}$ [20]. Growing body of evidence suggest that serum $25(\mathrm{OH})$ D cut-off $<50 \mathrm{nmol} / \mathrm{L}$ or $20 \mathrm{ng} / \mathrm{ml}$ may be associated with greater risk of non skeletal chronic diseases [21, 22].

Vitamin D deficiency is widespread in individuals irrespective of their age, gender, race and geography. Vitamin D is photosynthesized in the skin on exposure to UVB rays. Sun exposure alone is known suffice for vitamin D sufficiency.

Vitamin D deficiency is widely prevalent despite plentiful sunshine even in tropical countries like India. Vitamin D Deficiency is a major health problem in both the developed and developing countries across the globe.

In India, despite of ample sunlight (required for the synthesis of vitamin D endogenously), It has been 
documented to be in range of 50-90\% among all the age groups in India. Vitamin D deficiency can account for different morbidity occurring in the prevalence of obesity.

It may be possible to reverse the increasing prevalence of morbidity by improving vitamin D status [23]

Vitamin D deficiency has a bearing not only on skeletal but also on extra skeletal diseases. Owing to its multifarious implications on health, the epidemic of vitamin D deficiency in India is likely to significantly contribute to the enormous burden on the healthcare system of India.

Cultural and social taboos often dictate lifestyle patterns such as clothing - that may limit sun exposure and vegetarianism - which certainly limits vitamin D rich dietary options. Most Indians are vegetarians. The socioeconomically backward people constitute a large percentage of the population in India.

The underprivileged generally suffer from overall poor nutrition. Vitamin D rich dietary sources are limited and unaffordable to most Indians. Vitamin D supplements are available, but most Indians are not aware that they need additional vitamin D. Additionally, the cost of these supplements is essentially prohibitive to the majority.

Fortification of staple foods with vitamin D may prove to be a more viable solution towards attaining vitamin D sufficiency in India [24].

Obese individuals, as a group, have low plasma concentrations of 25-hydroxyvitamin D [25(OH)D], which are associated with increased plasma concentrations of parathyroid hormone. [25-29]. It has been proposed that production of the active vitamin $\mathrm{D}$ metabolite 1, 25-dihydroxyvitamin D increases in High
BMI individuals and this in turn exerts negative feedback control on the hepatic synthesis of 1, 25dihydroxyvitamin D. It has also been suggested that the metabolic clearance of vitamin D may increase in obesity, possibly with enhanced uptake by adipose tissue $[25,26]$.

Although the explanation for the increased risk of vitamin D deficiency in obesity is unknown, it has been postulated that obese individuals may avoid exposure to solar ultraviolet (UV) radiation, which is indispensable for the cutaneous synthesis of vitamin D3.

If the increased risk of vitamin D deficiency in obesity were the result of a primary alteration or a direct consequence of obesity itself then a rational intervention could be instituted [30].

Because vitamin D is fat soluble and is readily stored in adipose tissue, it could be sequestered in the larger body pool of fat of obese individuals. It is observed that blood vitamin D3 concentrations increased in both the obese and nonobese subjects after exposure to an identical amount of UV-B irradiation.

The obese subjects had a larger body surface area of exposure and therefore would be expected to produce more vitamin D3, resulting in higher blood vitamin D3 concentrations, than would the nonobese control subjects.

Further the alteration of the vitamin D endocrine system in obese subjects is characterized by secondary hyperparathyroidism which is associated with enhanced renal tubular reabsorption of calcium and increased circulating $1,25(\mathrm{OH}) 2 \mathrm{D}$.

The reduction of serum 25-OHD in them is attributed to feedback inhibition of hepatic synthesis of the precursor by the increased serum 1, 25(OH) 2D. Available 
evidence indicates that serum para thyroid hormone (PTH) is higher in obese than in nonobese young adults and declines with weight loss [31].

In view of these observations, we carried out an investigation to determine whether obesity modifies the calcium level and Vitamin D level in obese subjects.

The results of this study would give an insight into the prevalence of obesity in study population. It would also assess the relation between obesity and vitamin D \& serum calcium level.

\section{Materials and Methods}

The study population: The study included 150 normal subjects. Age and sex matched subjects from general population is enrolled in the study. We have included adolescent group of subjects in our study. Subjects with no pre existing diseases and not taking any nutritional supplements are included in the study. Subjects with history of hepatic or renal disorders are not included. None of them was taking any anticonvulsant medication or corticosteroids.

As the study was conducted in general hospital, subjects coming middle \& lower socioeconomic status were included in the study. Due to large variation in socioeconomic status, it was not taken as criteria for selection of patient.

The subjects were interrogated about the family history of overweight, obesity and those subjects with family history of obesity are excluded from the study. Serum calcium, serum Vitamin D levels are investigated and recorded.

Measurement: Serum calcium was measured by automated colorimetric methods. Serum 25(OH) Vitamin D level was measured by radioimmunoassay.

\section{Results}

The 150 individuals that are included in the study are investigated for serum $25(\mathrm{OH})$ vitamin $\mathrm{D}$ and serum ionized calcium level. Out of the 150 subjects included in the study, 107 subjects had Obesity and 43 subjects was non-obese. The statistical analysis was done by ' $t$ ' test. The values were expressed as Mean \pm SD. Then the two groups were compared statistically for serum $25(\mathrm{OH})$ vitamin D and serum calcium level. Interpretation was done according to $\mathrm{p}$ value i.e $* \mathrm{p}<0.05$ is considered significant, ${ }^{*} \mathrm{p}<0.001$ is considered highly significant and $\mathrm{p} \geq 0.05$ is considered not significant.

Table I: Comparison of serum 25(OH) Vitamin D level \& Serum Total calcium level in two groups.

\begin{tabular}{|c|c|c|c|c|c|c|c|}
\hline \multirow{2}{*}{ Parameters } & \multirow{2}{*}{$\begin{array}{c}\text { Reference } \\
\text { value }\end{array}$} & \multicolumn{3}{|c|}{ Obese subjects } & \multicolumn{3}{c|}{ Non- Obese subjetcs } \\
\cline { 3 - 7 } & & Min. & Max. & $\begin{array}{c}\text { Mean } \pm \\
\text { SD }\end{array}$ & Min. & Max. & Mean \pm SD \\
\hline $\begin{array}{c}\text { serum 25(OH) } \\
\text { Vitamin D level }\end{array}$ & $\begin{array}{c}\text { More than 20 } \\
\mathrm{ng} / \mathrm{ml}\end{array}$ & 8 & 15 & $13 \pm 1$ & 26 & 33 & $28 \pm 2$ \\
\hline $\begin{array}{c}\text { Serum Total } \\
\text { calcium level }\end{array}$ & $9-11 \mathrm{mg} / \mathrm{dl}$ & 11.9 & 13.5 & $13 \pm 0.1$ & 9.4 & 10.5 & $10 \pm 0.1$ \\
\hline
\end{tabular}

$\mathrm{t}$ value $=7.36, \mathrm{p}$ value $<0.0001$ 
Table II: Incidence of Vitamin D Deficiency in the two groups

\begin{tabular}{|c|c|c|c|}
\hline Vitamin D Status & Obese & Non- obese & Total Subjects \\
\hline Normal Vitamin D & $33(31 \%)$ & $35(81 \%)$ & 68 \\
\hline Vitamin D Deficiency & $74(69 \%)$ & $08(19 \%)$ & 82 \\
\hline Total & $\mathbf{1 0 7}$ & $\mathbf{4 3}$ & $\mathbf{1 5 0}$ \\
\hline
\end{tabular}

Table- III: Incidence of Hypercalcemia in the two groups

\begin{tabular}{|c|c|c|c|}
\hline Calcium Status & Obese & Non- obese & Total Subjects \\
\hline Normal & $30(28 \%)$ & $33(76 \%)$ & 63 \\
\hline Hypercalcemia & $77(72 \%)$ & $10(24 \%)$ & 87 \\
\hline Total & $\mathbf{1 0 7}$ & $\mathbf{4 3}$ & $\mathbf{1 5 0}$ \\
\hline
\end{tabular}

\section{Discussion}

In the present study, serum $25(\mathrm{OH})$ Vitamin D ranges from 8 to $15 \mathrm{ng} / \mathrm{ml}$ with mean value of $13 \mathrm{ng} / \mathrm{ml}$ in Obese Subjects. While the range was 26 to $33 \mathrm{ng} / \mathrm{ml}$ in non- obese subjects with mean of $\mathrm{ng} / \mathrm{ml}$ and this change were statistically significant $(\mathrm{p}<0.05)$. It suggests that the Obese Subjects has decreased serum 25(OH) Vitamin D as compared to that of non-obese control. Out of 107 obese subjects, 74 (69\%) had Vitamin D deficiency.

In the present study, serum Total Calcium level ranges from 11.9 to $13.5 \mathrm{ng} / \mathrm{ml} \&$ mean value of $13 \mathrm{mg} / \mathrm{dl}$ in Obese Subjects. While the range was 9.4 to $10.5 \mathrm{ng} / \mathrm{ml}$ in non- obese subjects with mean of $10 \mathrm{mg} / \mathrm{dl}$ and this change were statistically significant $(\mathrm{p}<0.05)$.
It suggestes that the Obese Subjects has increased serum total calcium as compared to that of non-obese control. Out of 107 obese subjects, 77 (72\%) had hypercalcemia.

Our results provide evidence that serum 25(OH) Vitamin $\mathrm{D}$ is low in obese individuals and these changes occurred with the changes in total calcium level. Collectively the results provide that the alteration in Vitamin D and Calcium level in obese individuals. Obese individuals tend to have low basal vitamin D and high parathyroid level than do non-obese individuals.

The obese subjects had a large body surface area of exposure and therefore would be expected to produce more vitamin $\mathrm{D}$ resulting in higher vitamin D

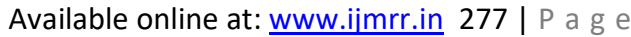


concentration than do non-obese control subjects. It was shown previously that serum PTH is abnormally increased in obese subjects, and that the values returned to the normal range with weight loss that was produced by intestinal bypass [32].

Further, the weight loss and decrease in circulating PTH correlated with each other. Previous studies show significant increases in mean serum PTH, serum $1,25(\mathrm{OH}) 2 \mathrm{D}$, and urinary cAMP, and significant decreases in mean serum 25-OHD and urinary calcium in obese as compared with nonobese white subjects (33). The finding that reduced serum 25- OHD returned to normal in a group of obese subjects after weight reduction produced by intestinal bypass is consistent with correction of secondary hyperparathyroidism (32) and increased circulating $1,25(0 \mathrm{H} 1) \mathrm{D}$ by weight loss.

Because humans obtain most of their vitamin D requirement from casual exposure to sunlight, the $>$ $50 \%$ decreased bioavailability of cutaneously synthesized vitamin D3 in the obese subjects could account for the consistent observation by us and others that obesity is associated with vitamin D deficiency.

Oral vitamin D should be able to correct the vitamin D deficiency associated with obesity, but larger than usual doses may be required for every obese subjects.

\section{Conclusion}

The study analysis of subjects with obesity for Vitamin $\mathrm{D}$ and serum calcium status suggests that Obesity is certainly a factor for developing Vitamin D Deficiency and hypercalcemia. It can be possible to decrease morbidity in obese individuals by improving Vitamin D status.

Funding: Nil,

Conflict of interest: None.

Permission of IRB: Yes

International Journal of Medical Research and Review

\section{References}

1. Flegal KM, Carroll MD, Kuczmarski RJ, Johnson CL. Overweight and obesity in the United States: prevalence and trends, 1960-1994. Int J Obes Relat Metab Disord. 1998 Jan;22(1):39-47.

2. Childhood obesity: an emerging public-health problem. Lancet. 2001 Jun 23;357(9273):1989.

3. Bennett N, Todd T, Flately J. Health survey for England 1993. London: Her Majesty's Stationery Office; 1995.

4. Obesity: preventing and managing the global epidemic. Report of a WHO Consultation on Obesity, Geneva, 3-5 June 1997. Geneva;World Health Organization; 1998. WHO document WHO/NUT/NCD/98.1.

5. Popkin BM, Doak CM. The obesity epidemic is a worldwide phenomenon. Nutr Rev. 1998 Apr;56(4 Pt 1):106-14.

6. Mann JI. Diet and risk of coronary heart disease and type 2 diabetes. Lancet. 2002 Sep 7;360 (9335): 783-9.

7.Must A, Spadano J, Coakley EH, Field AE, Colditz G, DietzWH.The disease burden associated withoverwe ight and obesity. JAMA. 1999 Oct 27;282(16):1523-9.

8. Allison DB, Zannolli R, Narayan KM. The direct health care costs of obesity in the United States. Am J Public Health. 1999 Aug;89(8):1194-9.

9. Sundquist J, Johansson SE. The influence of socioeconomic status, ethnicity and lifestyle on body mass index in a longitudinal study. Int $\mathrm{J}$ Epidemiol. 1998 Feb;27(1):57-63.

10. Ross JG, Pate RR, Lohman TG, Christenson GM. Changes in the body composition of children. J Phys Educ Rec Dance 1987; 58:74-77. 
11. Sundquist J, Johansson SE. The influence of socioeconomic status, ethnicity and lifestyle on body mass index in a longitudinal study.

12. Ogden CL, Flegal KM, Carroll MD, Johnson CL. Prevalence and trends in overweight among US children and adolescents, 1999-2000. JAMA. 2002 Oct 9;288(14):1728-32.

13. Power C, Lake JK, Cole TJ. Measurement and longterm health risks of child and adolescent fatness. Int $\mathbf{J}$ Obes Relat Metab Disord. 1997 Jul;21(7):507-26.

14. Bray GA, Bouchard C, James WPT. Handbook of Obesity. New York: Marcel Dekker; 1998.

15. Must A, Strauss RS. Risks and consequences of childhood and adolescent obesity. Int $\mathrm{J}$ Obes Relat Metab Disord. 1999 Mar;23 Suppl 2:S2-11.

16. Cole TJ, Bellizzi MC, Flegal KM, Dietz WH. Establishing a standard definition for child overweight and obesity worldwide: international survey. BMJ. 2000 May 6;320(7244):1240-3.

17.Guillaume M.Defining obesity in childhood: current practice. Am J Clin Nutr. 1999 Jul;70(1):126S-30S.

18. Zerwekh JE. Blood biomarkers of vitamin D status. Am J Clin Nutr. 2008 Apr;87(4):1087S-91S.

19. Thacher TD, Clarke BL, 2011 Vitamin D Insufficiency. Mayo Clin Proc. 86(1); 50-60. [6] Levis S, Gomez A, Jimenez C, et al. 2006 Vitamin d deficiency and seasonal variation in an adult South Florida population. J Clin Endocrinol Metab, 90;15571562.

20. Lips P. Vitamin D deficiency and secondary hyperparathyroidism in the elderly: consequences for bone loss and fractures and therapeutic implications. Endocr Rev. 2001 Aug;22(4):477-501.
21. Zittermann A, Schleithoff SS, Tenderich G, Berthold HK, Körfer R, Stehle P. Low vitamin D status: a contributing factor in the pathogenesis of congestive heart failure? J Am Coll Cardiol. 2003 Jan;41(1):105-12.

22. Holick MF. Sunlight and vitamin D for bone health and prevention of autoimmune diseases, cancers, and cardiovascular disease. Am J Clin Nutr. 2004 Dec;80(6 Suppl):1678S-88S.

23. Current status of Vitamin D deficiency disorders in India. Urvashi Mehlawat, et al., IPP, Vol 2 (2), 328335,2014

24. G R, Gupta A. Vitamin D deficiency in India: prevalence, causalities and interventions. Nutrients. 2014 Feb 21;6(2):729-75. doi: 10.3390/ nu6020729.

25. Bell NH, Epstein S, Greene A, Shary J, Oexmann MJ, Shaw S. Evidence for alteration of the vitamin Dendocrine system in obese subjects. J Clin Invest. 1985 Jul;76(1):370-3.

26. Liel Y, Ulmer E, Shary J, Hollis BW, Bell NH. Low circulating vitamin $\mathrm{D}$ in obesity. Calcif Tissue Int. 1988 Oct;43(4):199-201.

27. Compston JE, Vedi S, Ledger JE, Webb A, Gazet JC, Pilkington TR. Vitamin D status and bone histomorphometry in gross obesity. Am J Clin Nutr. 1981 Nov;34(11):2359-63.

28. Hey H, Stokholm KH, Lund B, Lund B, Sørensen $\mathrm{OH}$. Vitamin D deficiency in obese patients and changes in circulating vitamin D metabolites following jejunoileal bypass. Int J Obes. 1982;6(5):473-9.

29. Hyldstrup L, Andersen T, McNair P, Breum L,TransbølI.Bone metabolism in obesity: changes relate $\mathrm{d}$ to severe overweight and dietary weight eduction. Acta Endocrinol (Copenh). 1993 Nov;129 (5): 393-8. 
30. Wortsman J, Matsuoka LY, Chen TC, Lu Z, Holick

MF. Decreased bioavailability of vitamin D in obesity. Am J Clin Nutr. 2000 Sep;72(3):690-3.

31. Atkinson, R. L., W. T. Dahms, G. A. Bray, and A. A. Schwartz. 1978. Parathyroid hormone levels in obesity: effects of intestinal bypass surgery. Miner. Electrolyte Metab. 1:315-320.

32. Teitelbaum SL, Halverson JD, Bates M, Wise L, Haddad JG. Abnormalities of circulating 25-OH vitamin D after jejunal-lleal bypass for obesity: evidence of an adaptive response. Ann Intern Med. 1977 Mar;86(3):289-93.

33. Rickers H, Christiansen C, Balslev I, Rødbro P. Impairment of vitamin $\mathrm{D}$ metabolism and bone mineral content after intestinal bypass for obesity. A longitudinal study. Scand J Gastroenterol. 1984 Mar;19(2):184-9.

\section{How to cite this article?}

Shah P, Chauhan AP. Impact of obesity on vitamin D and calcium status. Int J Med Res Rev 2016;4(2):273-280. doi: 10.17511/ijmrr.2016.i02.022. 